\title{
Micro-Economics of Apoptosis in Cancer: ncRNAs Modulation of BCL-2 Family Members
}

\author{
Lidia Villanova ${ }^{1,+}$, Silvia Careccia ${ }^{2,+}$, Ruggero De Maria ${ }^{2, *}$ and Micol E. Fiori ${ }^{1, *}$ \\ 1 Department of Oncology and Molecular Medicine, Istituto Superiore di Sanità, 00161 Rome, Italy; \\ lidia.villanova@gmail.com \\ 2 Institute of General Pathology, Catholic University of the Sacred Heart and Gemelli Polyclinic, 00168 Rome, \\ Italy; silvia.care@gmail.com \\ * Correspondence: Ruggero.DeMaria@unicatt.it (R.D.M.); fiorimicol@gmail.com (M.E.F.); \\ Tel.: +39-06-49902059 (ext. 2776) (M.E.F.) \\ + These authors contributed equally to this work.
}

Received: 28 February 2018; Accepted: 21 March 2018; Published: 23 March 2018

\begin{abstract}
In the last few years, non-coding RNAs (ncRNAs) have been a hot topic in cancer research Many ncRNAs were found to regulate the apoptotic process and to play a role in tumor cell resistance to treatment. The apoptotic program is on the frontline as self-defense from cancer onset, and evasion of apoptosis has been classified as one of the hallmarks of cancer responsible for therapy failure. The B-cell lymphoma 2 (BCL-2) family members are key players in the regulation of apoptosis and mediate the activation of the mitochondrial death machinery in response to radiation, chemotherapeutic agents and many targeted therapeutics. The balance between the pro-survival and the pro-apoptotic BCL-2 proteins is strictly controlled by ncRNAs. Here, we highlight the most common mechanisms exerted by microRNAs, long non-coding RNAs and circular RNAs on the main mediators of the intrinsic apoptotic cascade with particular focus on their significance in cancer biology.
\end{abstract}

Keywords: microRNAs; long non-coding RNAs; BCL-2 family; apoptosis; cancer; therapy resistance

\section{Intrinsic Apoptotic Program}

The word "apoptosis" was coined from Greek to address a programmed cell death, which contributes to the tissue homeostasis as the "falling off" of autumn leaves in a tree [1]. The apoptotic machinery consists of both upstream regulators and downstream effectors [2]. The regulators are divided into two major circuits, one processing extracellular death-inducing cues (the "extrinsic" apoptotic program, involving for example the Fas ligand/Fas receptor) and the other (the "intrinsic" or "mitochondrial" program) sensing a variety of stress signals of intracellular origin such as DNA damage, accumulation of reactive oxygen species (ROS), $\mathrm{Ca}^{2+}$ overload, survival factors' deprivation or oncogene activation. Each program leads to the activation of a normally latent cysteine protease (caspase 8 or 9, respectively), which triggers a cascade of proteolytic events involving effector caspases 3 and 7 responsible for the execution phase of apoptosis, resulting in the progressive disassembly of cellular structures and ultimately engulfment by phagocytic cells.

Mitochondria are the cells' energy factories, but also the organelles where suicidal signals converge and are executed. The intrinsic apoptotic program is more widely implicated as a barrier to cancer pathogenesis [3]. It culminates in mitochondrial outer membrane permeabilization (MOMP), followed by the release into the cytosol of cytotoxic proteins normally confined within the mitochondrial intermembrane space (IMS). Such cytotoxic proteins include caspase activators such as cytochrome C and DIABLO, as well as caspase-independent cell death effectors like apoptosis-inducing factor and endonuclease G. 
Proteins belonging to the BCL-2 family are the key regulators of MOMP. This family consists of three groups of structurally-related proteins: the pro-survival BCL-2-like proteins (BCL-2, BCL-XL, BCL-W, MCL-1, BFL-1), the pro-apoptotic multi-BH domain BAX/BAK proteins and the pro-apoptotic BH3-only proteins (BIM, PUMA, BID, BAD, BIK, BMF, NOXA, HRK). In healthy cells, BAX and BAK are kept inactive by the interaction with pro-survival members $[4,5]$. In response to pro-apoptotic signals, BAX and BAK can trigger MOMP by inducing the formation of protein-permeable pores in the mitochondrial outer membrane that allow the release of IMS proteins into the cytosol [6]. BH3-only proteins share significant homology within the BCL-2 homology 3 (BH3) domain and act as intracellular stress sensors. All BH3-only proteins can indirectly activate BAX/BAK by sequestering their pro-survival BCL-2-like relatives, whereas only some of them can also trigger BAX/BAK activation through direct binding (Table 1) [7,8].

Table 1. STRING software was used to search for each BH3-only protein interactors. Only experimentally-validated interactions with a minimum score of 0.4 (medium confidence) are reported in the table. Interactors reported for HRK were identified by searching with a minimum score of 0.15 (low confidence).

\begin{tabular}{cccc}
\hline BH3-Only Proteins & p53 Transcriptional Targets & Pro-Survival Interactors & Direct Activation of BAX/BAK \\
\hline BAD & No & BCL-2, BCL-XL, BFL-1, MCL-1 & - \\
BID & No & BCL-2, BCL-XL, BFL-1, MCL-1 & $\sqrt{ }$ \\
BIK & No & BCL-2, BCL-XL, BCL-W & - \\
BIM & No & BCL-2, BCL-XL, BFL-1, MCL-1 & $\sqrt{ }$ \\
BMF & No & BCL-2, BCL-XL, BFL-1, MCL-1 & - \\
HRK & No & BCL-2, BCL-XL, MCL-1 & - \\
NOXA & Yes & BCL-2, BCL-XL, BFL-1, MCL-1 & - \\
PUMA & Yes & BCL-2, BCL-XL, BFL-1, MCL-1 & - \\
\hline
\end{tabular}

\section{BCL-2 Family Members in Cancer Onset, Progression and Resistance to Therapy}

Evasion of apoptosis has been classified as one of the hallmarks of cancer [9] and is among the main causes of therapy failure. Most tumors are defective in the activation of apoptosis owing to the occurrence of genetic or epigenetic events that either inactivate the p53 pathway or provoke aberrant expression of pro-survival BCL-2 family members including BCL-2, BCL-XL or MCL-1 $[10,11]$. It has been shown that BCL-2 exerts a key role in tumorigenesis. In a mouse model of APC-loss induced colorectal cancer, BCL-2-dependent impairment of apoptosis is required for carcinoma onset [12]. Importantly, such unbalance in favor of the pro-survival side of the BCL-2 family confers resistance to radiation, chemotherapeutic agents and many selective pathway inhibitors that induce apoptosis primarily through the activation of the mitochondrial death machinery. Notably, a recently-developed functional assay called "BH3 profiling" allows assessing the extent of mitochondrial sensitivity to the induction of MOMP by measuring mitochondrial depolarization upon cells' exposure to peptides derived from $\mathrm{BH} 3-$-only proteins. $\mathrm{BH} 3$ profiling of tumors has been proposed as a tool for predicting chemotherapy sensitivity, since the extent of "mitochondrial priming" in several tumor types was found to correlate with clinical response to cytotoxic chemotherapy [13].

Noteworthy, some BCL-2 family proteins are involved in other cancer hallmarks besides apoptosis resistance. BCL-W expression was reported to be upregulated in the infiltrative types of gastric cancer [14] and in glioblastoma multiforme biopsies (WHO Grade IV) compared with glioma (WHO Grade III) and normal tissues [15], suggesting a role in tumor progression. Bae and colleagues provided a mechanistic insight, showing that BCL-W ectopic expression enhanced the invasive potential of gastric cancer and glioblastoma cell lines by inducing MMPs expression via a PI3K-AKT-mediated activation of SP1 and $\beta$-catenin, respectively $[15,16]$.

In a bi-transgenic mouse model engineered to spontaneously develop pancreatic neoplasia, BCL-XL viral transduction in hyperplastic or early dysplastic lesions increased tumor invasion and facilitated lymph node metastasis, without altering cancer cell survival or proliferation [17]. BCL-XL-induced increase in the migratory and invasive potential was confirmed in pancreatic cancer 
cell lines, and a remodeling of the actin cytoskeleton was observed in both cell cultures and pancreatic cancer xenografts. Downregulation of E-cadherin expression and co-immunoprecipitation of BCL-XL with myosin $\mathrm{Va}$, besides BAX and BAD, shed light on the molecular mechanisms underlying the observed phenotypes. More recently, BCL-XL was shown to promote stemness and to contribute to the aggressiveness of both melanoma and glioblastoma [18]. Further, by testing apoptosis-defective mutants in pancreatic neuroendocrine tumor (panNET) and breast cancer cell lines, Choi and colleagues demonstrated that BCL-XL promotes metastasis independently of its anti-apoptotic activity. They provided evidence for BCL-XL nuclear functions involving epigenetic activation of TGF $\beta$ promoter, thus boosting TGF $\beta$ signaling [19].

BCL-2 was reported to have a role in tumor onset, spread and therapy resistance that does not rely uniquely on the apoptotic pathway. Human lung epithelial cells chronically exposed to the carcinogenic hexavalent chromium $\mathrm{Cr}(\mathrm{VI})$ undergo transformation that strongly relies on BCL-2. Medan and colleagues showed that BCL-2 drives invasive and proliferative properties of the transformed cells, as well as their colony-forming and angiogenic activities [20]. Further, BCL-2 was found to stimulate epithelial to mesenchymal transition (EMT) in pre-malignant mammary epithelial cells and in hepatocarcinoma cells, where the formation of a BCL-2/TWIST1 complex facilitates the nuclear transport of TWIST1, leading to transcriptional activation of TWIST target genes that sustain tumor cell plasticity, metastasis and vasculogenic processes [21,22].

Overall, these results point out the involvement of BCL-2, BCL-W and BCL-XL in molecular events not related to the apoptotic cascade. These "other" cellular activities have been linked to the BH4 domain, which mediates direct interactions with specific proteins functionally implicated in distinct stages of tumor progression. Lately, recent efforts are aiming at developing new inhibitors directed against the BH4 domain, which is considered an appealing target due to its unique structure and crucial involvement in many cellular functions [23].

\section{Different Layers of Regulation of BCL-2 Family Members by ncRNAs}

BCL-2 family proteins are subjected to several layers of regulation that affect transcript levels and protein half-life, phosphorylation status and localization. Besides p53-mediated transcriptional activation of PUMA and NOXA following DNA damage [24], other transcription factors were found to regulate BH3-only proteins including E2F1 [25], FOXO3a [26], CHOP [27] and NF-Y [28]. Interestingly, NF-YA was found to play a role in the differential kinetics of the induction of p53 target genes upon cellular stress. Indeed, orchestration of p53 stress response relies on earlier expression of cell cycle arrest-related genes compared to pro-apoptotic genes [29]. This is accomplished by NF-YA recruitment to the promoters of the pro-apoptotic subset, where it affects RNA PolII recruitment and processivity [30]. Control over protein stability is exemplified by MCL-1 degradation by the ubiquitin ligases MULE and FBW7 [31,32]. In addition to modifying protein levels, activities of BCL-2 proteins including BCL-XL, NOXA, BIM, BAK and BAX can be modified by protein phosphorylation [33-38]. Further, the localization of BCL-2 proteins can be influenced by upstream factors. For example, BAX is constrained at the Golgi until being released by DNA damage signals [39] or maintained in the cytoplasm by BCL-XL [40]. Finally, the expression of the BCL-2 family proteins can be modulated through the activity of ncRNAs.

Here, we aim to outline the most relevant regulatory strategies involving ncRNAs that human cells evolved to control cell death and their implications in cancer biology (Figure 1 and Table 2). 


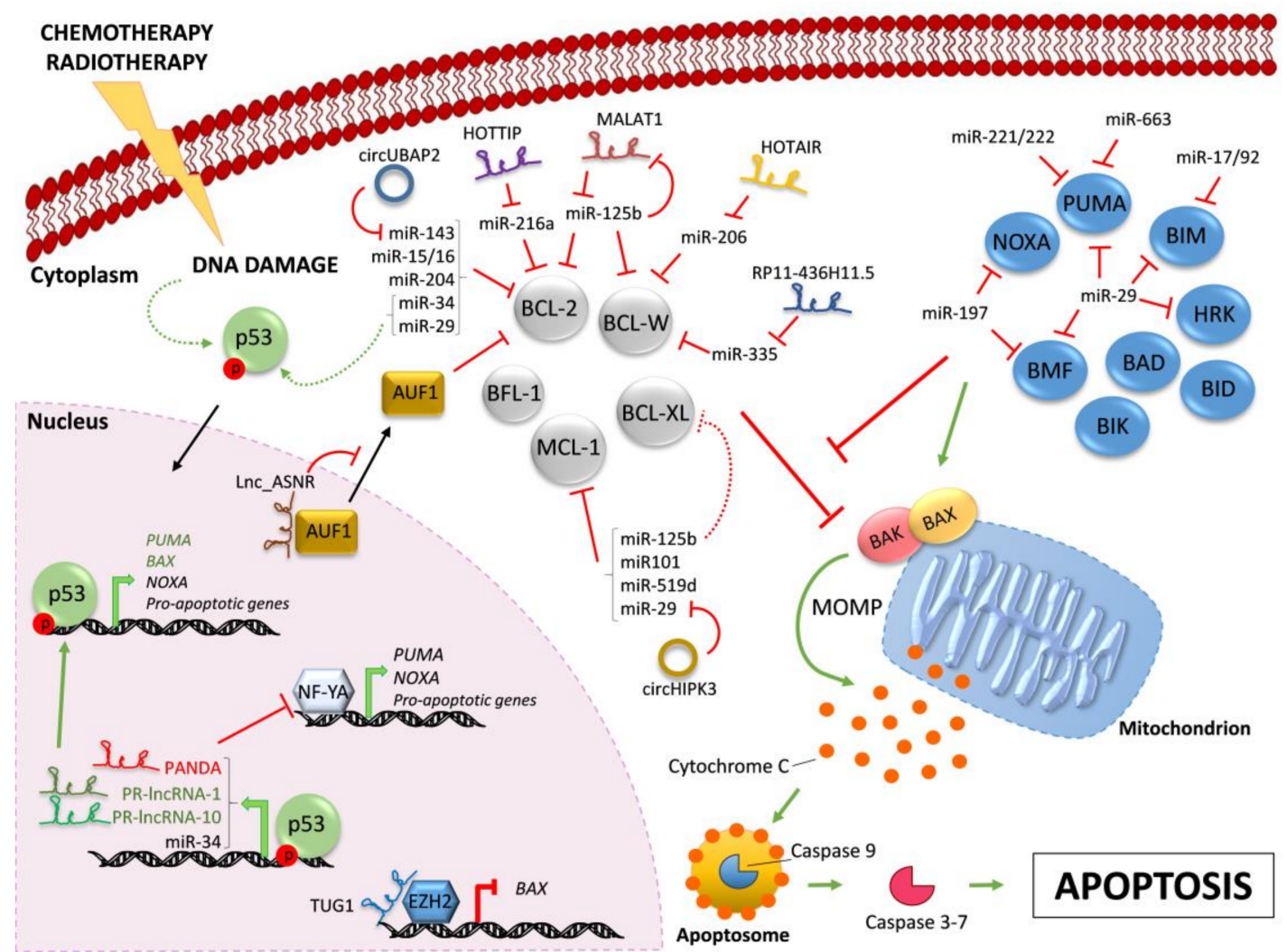

Figure 1. Regulation of BCL-2 family members by ncRNAs. Chemotherapy and/or radiotherapy induce DNA damage that leads to the activation of p53 (dashed curve green arrow). Active p53 translocates into the nucleus and drives the transcription (bold green arrows) of the indicated pro-apoptotic proteins and ncRNAs. Indicated lncRNAs control the transcription of pro-apoptotic proteins by different mechanisms. The pro-apoptotic multi-BH domain BAX and BAK are kept inactive by the interaction with pro-survival BCL-2-like proteins (in grey). All BH3-only proteins (in blue) can indirectly activate BAX/BAK by sequestering their pro-survival BCL-2-like relatives (red line), whereas only some of them can also trigger BAX/BAK activation through direct binding (green arrow). Active BAX/BAK oligomerize on the mitochondria membrane and lead to mitochondrial outer membrane permeabilization (MOMP) and consequent Cytochrome $C$ release in the cytoplasm. Activation of downstream caspase cascade ultimately triggers apoptosis. In the cytoplasm, microRNAs negatively regulate BH3-only proteins and pro-survival BCL-2 family members. Indicated lncRNAs and circRNAs act as miR-sponges, counteracting miR-mediated regulation of pro-survival proteins. Further, MALAT1 is down-regulated by miR-125b, in a negative feedback-loop. Red lines indicate inhibition; green arrows indicate activation. Continuous arrows and lines refer to direct regulation; dashed arrows and lines indicate indirect regulation. Black arrows indicate nuclear/cytoplasmic translocations.

\subsection{MicroRNAs}

MicroRNAs (miRNAs) are small ( 22 nt) single-stranded non-coding RNAs responsible for post-transcriptional control of gene expression. miRNAs exert their regulatory function through Watson-Crick base pairing of their $5^{\prime}$ region (seed sequence) with the target mRNA, generally in the $3^{\prime}$ UTR [41]. Regulation by miRNAs involves a plethora of biological processes, such as cell differentiation, proliferation, metabolism and apoptosis. It is therefore not surprising that dysregulation of miRNAs' expression plays an important role in cancer biology [42]. Aberrant expression of miRNAs in cancer was first reported in 2002 when Calin et al. demonstrated the downregulation of the miRNA cluster miR-15/16 in chronic lymphocytic leukemia (CLL). The miR-15/16 cluster is located on chromosome 13q14, a region deleted in more than half of the cases of CLL and B-cell leukemia [43]. Notably, one of 
the miR-15/16 targets is BCL-2, which has a critical role in the malignant transformation of solid tissues, as well as lymphoid cells [44]. Following this first finding, a large number of miRNAs controlling the expression of BCL-2 family members has been identified. In 2011, a high-throughput approach integrating expression profiling and in silico prediction was employed to identify a set of miRNAs targeting BCL-2 [45]. An intriguing mechanism of BCL-2 regulation was shown in 2015 by Kuwano and colleagues. In colon cancer cells, the authors found that transformer $2 \beta$ (Tra2 $\beta$ ), a splicing factor overexpressed in many cancer tissues, modulates the accessibility of the miR-204 binding site on $B C L-2$ $3^{\prime}$ UTR by competitive binding, thus stabilizing BCL-2 mRNA [46].

The broad regulatory power of microRNAs relies on their ability to control whole pathways or even multiple complementary pathways by regulating the expression of different actors of the same set. Our group reported on the role of miR-197 and miR-663 in conferring apoptosis resistance in non-small cell lung (NSCL) cancer. Briefly, miR-197 behaves as a master regulator of the apoptotic response in p53 wt background by targeting NOXA and BMF [47]. MiR-663 inhibits mitochondrial outer membrane permeabilization (MOMP), downregulating PUMA and preventing p53 mitochondrial accumulation by repressing BTG2 expression [48]. Further, we showed how the miR-17-92 cluster, under the transcriptional control of N-MYC, inhibits the expression of p21 and BIM in neuroblastoma, orchestrating uncontrolled cell proliferation and apoptotic escape [49]. Another example of simultaneous regulation of multiple proteins belonging to the BCL-2 family is miR-29. During neuronal development, miR-29 expression progressively increases, and it is kept at sustained levels throughout mature neurons' lifespan to prevent apoptosis triggering in response to different stress-inducing conditions. This pro-survival action of miR-29 ensures neuron preservation during the lifetime of the organism and is carried out by targeting different members of the pro-apoptotic BH3-only subfamily (BIM, BMF, HRK, PUMA, N-BAK) [50]. Conversely, in cancerous background, miR-29 exerts a pro-apoptotic role by multiple regulation of apoptosis effectors. Specifically, miR-29 was shown to induce apoptosis by directly targeting BCL-2 and MCL-1 and by indirectly activating p53 through the suppression of its inhibitors p85 $\alpha$ and CDC42 [51-54]. Consistent with an oncosuppressive role, downregulation of miR-29 has been reported in multiple cancer types, where its critical role in tumorigenesis and cancer progression has been described [55].

Further, microRNAs can take part in complex regulatory circuitries, involving protein factors and other ncRNAs, where the activity of main effectors of pivotal cellular functions are finely modulated in response to intra- and extra-cellular stimuli. One striking example of such intriguing connections is the miR-34 family. MiR-34, a p53-induced microRNA, functions as a tumor suppressor by playing a role in cell cycle arrest, apoptosis and metabolic regulation [56-58]. miR-34 targets include the anti-apoptotic factors BCL-2, sirtuin 1 (SIRT1) and MDM4 [59]. While p53 induces the transcription of miR-34, this miRNA in turn represses MDM4 and/or SIRT1 to enhance p53 transcription activity and decrease p53 protein turnover in a positive feedback loop that boosts a robust tumor suppressive response [60]. Restoration of miR-34 expression in p53-deficient cancer cells could be exploited to restore chemosensitivity to drugs that rely on p53-mediated apoptosis, as was shown in gastric cancer cells [61].

As discussed above, pro-survival members of the BCL-2 family are involved in several hallmarks of cancer, spanning from invasion and metastasis to angiogenesis and DNA replication and repair [62]. Interestingly, miR-335 was unveiled to suppress the invasive and metastatic properties of gastric cancer cells by targeting BCL-W and SP1, and low expression of miR-335 was significantly associated with lymph-node metastasis, poor $\mathrm{pT}$ and $\mathrm{pN}$ stage, underscoring the prognostic potential of miR-335 profiling [63]. miR-335 was also found downregulated in clear cell renal carcinoma (ccRCC), and its overexpression significantly inhibits the proliferation and invasion of ccRCC cells through direct BCL-W targeting [64].

Multi-drug resistance (MDR) is one of the major dilemmas in cancer therapy, due to mutations, changes in gene expression and drug-induced karyotypic alterations. The BCL-2 family is known to have a major role in tumor evasion of drug-induced cell death [65]. MiRNAs have been explored as 
good candidates to overcome MDR, and a wide body of evidence shows that miRNAs can sensitize cancer cells to drug treatments. Indeed, microRNA-mediated modulation of BCL-2 family proteins proved to be an effective anti-cancer strategy in combinatorial therapies in pre-clinical models, resulting in cancer sensitization to chemotherapy. For example, miR-125b was found to sensitize hepatocellular carcinoma (HCC) cells to chemotherapeutic treatment by directly targeting MCL-1, BCL-W and indirectly targeting BCL-XL [66]. Indeed, doxorubicin-treated HCC cell lines showed a marked increase in apoptosis when miR-125-b was overexpressed, due to a downregulation of the anti-apoptotic proteins. On the contrary, inhibition of miR-125b significantly reduced drug-induced apoptosis. Another microRNA targeting MCL-1 in HCC is miR-101. Combining low doses of doxorubicin with miR-101 mimic was sufficient to significantly induce MCL-1-dependent apoptosis, thus suggesting a good strategy to overcome the toxicity of doxorubicin treatment observed in clinics [67-69]. Downregulation of MCL-1 by miRNAs was found to affect also the cancer stem cell (CSC) population in breast cancer. CSCs are resistant to chemotherapy and therefore are mainly responsible for treatment failure in patients. miR-519d was found to sensitize CSCs to cisplatin treatment by targeting MCL-1. MiR-519d overexpression or MCL-1 silencing alone did not affect CSCs' viability, while the combination with cisplatin led to increased apoptosis of CSCs [70]. Furthermore, miR-34 was found to play a role in CSCs' self-renewal and survival. MiR-34 was reported to be downregulated in the CD44+/CD133+ pancreatic CSC population, accompanied by high levels of its target gene BCL-2. Moreover, restoring miR-34 expression was shown to inhibit cell clonogenic growth and to increase cell death and response to chemo-/radio-therapy of pancreatic CSCs by the simultaneous inhibition of its downstream target genes Notch and BCL-2 [71].

Interestingly, the miR-221/222 cluster is one of the most commonly upregulated miRNAs in human solid and hematologic tumors, and it was found to target multiple BH3-only pro-apoptotic proteins. The role of the miR-221/222 cluster was studied in a model of dexamethasone-induced drug resistance in multiple myeloma (MM). By using the isogenic cell lines MM1R and MM1S, respectively resistant and sensitive to dexamethasone, the authors identified DNA copy number gains in MM1R cells that were associated with increased miR-221-222 expression and consequent downregulation of its target PUMA. Modulation of the miR-221/222 cluster alone was able to revert the resistance of MM1R cells and conversely to confer resistance to sensitive MM1S cells, thus demonstrating the key role of these microRNAs as mediators of resistance in MM. These data were consistent with observed overexpression of this miR cluster together with the decrease of PUMA in relapsed patients [72].

\subsection{Long non-Coding RNAs}

Multiple regulatory mechanisms targeting BCL-2 family members involve a different class of non-coding RNAs called long non-coding RNAs (lncRNAs).

LncRNAs have recently jumped on the non-coding RNA stage as crucial regulators of gene expression through a wide variety of molecular mechanisms. These transcripts $>200 \mathrm{bp}$ in length fold into evolutionarily-conserved secondary structures and exert their regulatory functions at different levels by recruiting chromatin modifiers or transcription factors on gene promoters, by affecting the assembly of protein complexes, by interfering with mRNA processing or behaving as microRNA sponges (competing endogenous RNAs (ceRNAs)) [73,74]. The identification of a plethora of lncRNAs differentially expressed in tumors relative to normal tissues or at different tumor stages hinted at their potential as diagnostic, prognostic and predictive biomarkers. Several lncRNAs dysregulated in cancer have been reported to mediate escape from apoptosis through different mechanisms.

Lnc_ASNR (apoptosis suppressing non-coding RNA) was identified through transcriptome profiling of different tumor specimens (gastric, colon, liver and lung) where it was found upregulated. Further analyses unveiled that $l n c_{-} A S N R$ exerted a pro-survival role in tumor cells by promoting nuclear retention of the RNA binding protein AUF1 that in physiological conditions mediates $B C L-2$ mRNA degradation [75]. The finding that metastasis-associated lung adenocarcinoma transcript 1 (MALAT1) behaves as a ceRNA targeting tumor suppressor miR-125b unveiled a negative feedback 
loop in bladder cancer [76]. In fact, the same group had previously identified MALAT1 as a target of miR-125b overexpressed in bladder cancer [77]. More recently, using CRISPR-mediated MALAT1 activation or interference, the authors demonstrated that MALAT1 induces miR-125b degradation through the Ago2 complex, resulting in concurrent upregulation of miR-125b target genes $B C L-2$ and MMP13. Accordingly, silencing of BCL-2 and MMP13 neutralized the anti-apoptotic and invasion-promoting effect of miR-125b inhibitor on MALAT1 knockdown cells, thus confirming the role of these proteins in the establishment of cancer phenotypes in a MALAT1-overexpressing background. Further, BCL-2 upregulation mediated by lncRNA HOTTIP (HOXA distal transcript antisense RNA) was found to underlie chemoresistance in small cell lung cancer (SCLC) [78]. HOTTIP expression was increased in human SCLC chemoresistant cell lines and tissues compared to their chemosensitive counterparts. Noteworthy, the manipulation of HOTTIP expression affected the drug resistance of SCLC cell lines, measured as changes in the $\mathrm{IC}_{50}$. In addition, the combination of HOTTIP knockdown and administration of cisplatin and etoposide upon subcutaneous injection in mice of chemoresistant cells showed an additive effect in reducing tumor burden. Mechanistically, HOTTIP acts as a competing endogenous RNA by binding miR-216a, thus abolishing the miRNA-induced downregulation of BCL-2. As described for BCL-2, IncRNAs can post-transcriptionally upregulate the anti-apoptotic relatives of the BCL-2 family by acting as miRNA decoys. In breast cancer, high expression of BCL-W showed a positive correlation with lncRNA HOX transcript antisense RNA (HOTAIR) levels. Mechanistically, HOTAIR was demonstrated to titer away miR-206, thereby relying on the BCL-W transcript from miRNA-induced repression [79]. A similar molecular circuitry occurred in renal cell carcinoma, where BCL-W expression was boosted owing to lncRNA RP11-436H11.5 competitive binding to miR-335-5p [80].

LncRNA taurine upregulated 1 (TUG1) provides an interesting example of epigenetic regulation of BAX transcription. TUG1 aberrant expression in serum samples from lung adenocarcinoma patients compared to healthy donors showed a correlation with tumor size, degree of differentiation, metastasis and TNM stage. RNA immunoprecipitation (RIP) and RNA pulldown assays in lung adenocarcinoma cells demonstrated the interaction between TUG1 and the histone methyltransferase EZH2. Chromatin immunoprecipitation (ChIP) analysis revealed that TUG1 mediates epigenetic silencing of BAX promoter through EZH2 recruitment and consequent H3K27 hypermethylation, hence conferring tumor cells' protection against apoptotic triggers [81].

Moreover, IncRNAs proved to play a pivotal role in the activation of the p53-driven transcriptional program in response to DNA damage. By integrating RNA-seq with p53 ChIP-seq analyses in a colorectal cancer cell line under DNA damage, a signature of eighteen p53-regulated lncRNAs was identified [82]. Among them, $P R-\ln c R N A-1$ and $P R-\ln C R N A-10$ were required for the efficient binding of p53 to some of its target genes including BCL2L1, PUMA and BAX, contributing to apoptosis triggering upon DNA damage. Interestingly, some of the identified lncRNAs constituted a tumor suppressor signature with diagnostic power in colorectal cancer. Conversely, lncRNA PANDA, also transcribed via p53 following DNA damage, was demonstrated to hinder NF-YA-dependent transcription of PUMA, NOXA and other pro-apoptotic genes. Briefly, p53 binding at the CDKN1A locus coordinately activates expression of $\mathrm{p} 21$, as well as antisense noncoding transcript $P A N D A$, which in turn promote cell cycle arrest and apoptosis blockade, respectively [83].

\subsection{Circular RNAs}

In the diverse landscape of non-coding RNAs, circular RNAs (circRNAs) represent a novel class that has gained increasing consideration. These covalently-closed circular structures arise from either exon skipping or direct back-splicing. Exon skipping leads to a lariat that later on undergoes circularization, whereas direct back-splicing refers to the coupling of a donor splice site with an upstream unspliced acceptor site, which results in the circularization of the intervening RNA. CircRNAs are highly stable in vivo compared with linear RNAs, mainly localized in the cytoplasm and can be detected in exosomes [84]. Recently, circRNAs have been shown to act as microRNA 
sponges to regulate gene expression $[85,86]$. The pro-proliferative circHIPK3 was enriched in an RIP for Ago2, and a luciferase screening for an miRNA library identified nine growth-suppressive miRNAs that were sponged by this circular RNA, including miR-29 [52,87]. CircUBAP2, whose expression positively correlated with osteosarcoma progression, prevented apoptosis by raising BCL-2 expression through miR-143 sponging [88]. Circ-Foxo3 induces cell death through a different mechanism involving the regulation of the host gene transcript that eventually leads to PUMA overexpression. Circ-Foxo3 is downregulated in breast cancer specimens compared to the adjacent normal tissue, and nanoparticle-mediated delivery of a circ-Foxo3 plasmid in xenografts resulted in smaller tumors displaying a high percentage of TUNEL-positive cells [89]. Mechanistically, circ-Foxo3 exerts a tumor suppressor role by functioning as a scaffold for the assembly of the p53-MDM2 complex, hence releasing FOXO3 protein from MDM2-mediated ubiquitination and degradation. The resulting upregulation of the FOXO3 downstream target PUMA triggers apoptosis.

Table 2. ncRNAs regulating apoptosis by BCL-2 family members' modulation.

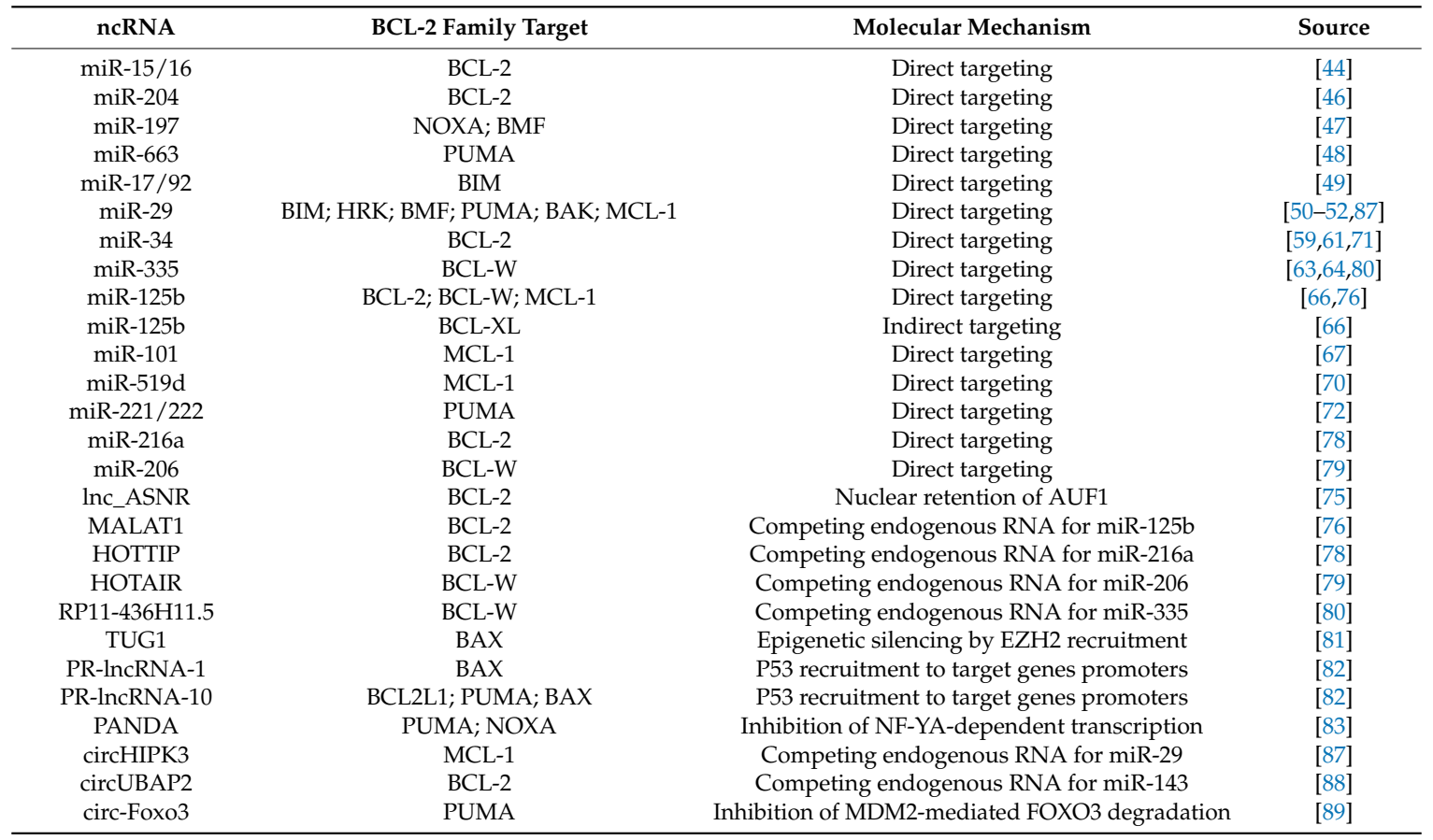

\section{Concluding Remarks}

The identification of the growing family of ncRNAs has broadened the vision of gene expression regulation, providing further layers of complexity that explain the capability of cells to rapidly adapt to external and internal stimuli [90]. Moreover, the large number of ncRNAs discovered so far provided a rationale to elucidate the contradiction between the huge extent of the human genome, $76 \%$ of which is actively transcribed as unveiled by the recent ENCODE project, and the relatively restricted number of protein-coding genes (about 20-25,000) [91,92]. The "one gene, one enzyme" paradigm stated by George Beadle in 1945 is nowadays completely reverted mainly due to ncRNAs. In this review, we focused on the role of three major classes of ncRNAs (miRNAs, lncRNAs and circRNAs) in the regulation of intrinsic apoptosis and more specifically of the BCL-2 protein family. BCL-2 family members have emerged as master regulators of the mitochondrial apoptotic machinery and potential therapeutic targets owing to their ability to induce MOMP following a wide range of stress insults, including anti-cancer drugs. Consistently, shifting the balance towards the pro-apoptotic members of the BCL-2 family may represent a powerful therapeutic strategy to overcome mechanisms of apoptosis resistance in cancer. By mimicking BH3-only proteins, $\mathrm{BH} 3$ mimetic drugs competitively bind pro-survival members of the BCL-2 family, thus displacing sequestered 
pro-apoptotic proteins [93]. The first developed compound ABT-737, targeting BCL-2, BCL-XL and BCL-W, exhibited single-agent antitumor activity in preclinical models of lymphoma and small-cell lung cancer (SCLC), as well as in primary patient-derived CLL samples [94]. Its orally-available analogue ABT-263 (Navitoclax) proved to be effective in phase I and II clinical trials in CLL, both as monotherapy [95] and in combination with standard cytotoxic chemo-immunotherapy regimens $[96,97]$. Unfortunately, the emergence of thrombocytopenia owing to BCL-XL targeting in platelets put a halt to its use in the clinic $[98,99]$. Development of the BCL-2-selective inhibitor ABT-199 (Venetoclax) circumvented this obstacle [100], and a successful phase II clinical trial in poor prognosis relapsed or refractory CLL patients led to the U.S. Food and Drug Administration (FDA) registration for Venetoclax [101]. However, innate or acquired MCL-1-dependent resistance represents the Achilles' heel of ABT-737, Navitoclax and Venetoclax [102,103]. Among MCL-1-selective inhibitors that have been recently developed [104], AMG176 is the first compound to have reached phase I clinical evaluation (ClinicalTrials.gov identifier: NCT02675452). In addition to functional inhibitors, alternative strategies to counteract MCL-1 resistance have been explored, such as downregulation of MCL-1 expression by caloric restriction in B-cell lymphoma [105] or by cardiac glycoside UNBS1450 in AML [106]. Here, we have described several microRNAs targeting MCL-1 that have been shown to sensitize cancer cells to cytotoxicity induced by either chemotherapeutics (miR-125b, miR-101, miR-519d) or TRAIL (TNF-related apoptosis-inducing ligand) treatment (miR-29) [52]. Combining BH3 mimetics with mimics of these microRNAs may be a promising therapeutic option for cancers displaying MCL-1-mediated resistance.

Besides MCL-1-mediated resistance, modulation of ncRNAs controlling the BCL-2 family, alone or in combination with other agents, could be explored as a therapeutic strategy against cancer [107]. Unfortunately, despite the large body of pre-clinical evidence, development of ncRNA-targeted therapeutics has slowed down owing to systemic delivery issues and the emergence of toxicities. However, novel delivery strategies have been optimized, raising the hope of translating such broad regulatory potential into effective molecules in the clinical setting. EnGeneIC Delivery Vehicle (EDV) nanocells (also called TargomiRs) are bacteria-derived particles that can be modified with surface-conjugated antibodies to enable tissue-specific targeting [108]. EDV nanocells coated with epidermal growth factor receptor (EGFR)-specific antibodies entered a phase I trial for the delivery of miR-16 mimics in patients with malignant pleural mesothelioma or non-small cell lung cancer (NSCLC). The results of this first-in-man study of TargomiRs showed that a dose of $5 \times 10^{9}$ TargomiRs per week was well tolerated and was accompanied by early signs of antitumor activity. These encouraging data support additional studies of miR-16-based TargomiRs in combination with chemotherapy or immune checkpoint inhibitors [109]. Furthermore, the application of these new frontiers of delivery to the modulation of microRNAs involved in the control of apoptosis will hopefully lead to effective therapeutic strategies to hit cancer and overcome resistance and recurrence.

Acknowledgments: Ruggero De Maria was supported by the Italian Association for Cancer Research (AIRC) (Investigator Grant 17621). Lidia Villanova is the owner of a fellowship award from Italian Foundation for Cancer Research (FIRC).

Conflicts of Interest: The authors declare no conflict of interest.

\section{References}

1. Kerr, J.F.; Wyllie, A.H.; Currie, A.R. Apoptosis: A basic biological phenomenon with wide-ranging implications in tissue kinetics. Br. J. Cancer 1972, 26, 239-257. [CrossRef] [PubMed]

2. Adams, J.M.; Cory, S. The Bcl-2 apoptotic switch in cancer development and therapy. Oncogene 2007, 26, 1324-1337. [CrossRef] [PubMed]

3. Fulda, S.; Galluzzi, L.; Kroemer, G. Targeting mitochondria for cancer therapy. Nat. Rev. Drug Discov. 2010, 9, 447-464. [CrossRef] [PubMed] 
4. Willis, S.N.; Chen, L.; Dewson, G.; Wei, A.; Naik, E.; Fletcher, J.I.; Adams, J.M.; Huang, D.C. Proapoptotic Bak is sequestered by Mcl-1 and Bcl-xL, but not Bcl-2, until displaced by BH3-only proteins. Genes Dev. 2005, 19, 1294-1305. [CrossRef] [PubMed]

5. Willis, S.N.; Fletcher, J.I.; Kaufmann, T.; van Delft, M.F.; Chen, L.; Czabotar, P.E.; Ierino, H.; Lee, E.F.; Fairlie, W.D.; Bouillet, P.; et al. Apoptosis initiated when BH3 ligands engage multiple Bcl-2 homologs, not Bax or Bak. Science 2007, 315, 856-859. [CrossRef] [PubMed]

6. Bleicken, S.; Landeta, O.; Landajuela, A.; Basanez, G.; Garcia-Saez, A.J. Proapoptotic Bax and Bak proteins form stable protein-permeable pores of tunable size. J. Biol. Chem. 2013, 288, 33241-33252. [CrossRef] [PubMed]

7. Chen, L.; Willis, S.N.; Wei, A.; Smith, B.J.; Fletcher, J.I.; Hinds, M.G.; Colman, P.M.; Day, C.L.; Adams, J.M.; Huang, D.C. Differential targeting of prosurvival Bcl-2 proteins by their BH3-only ligands allows complementary apoptotic function. Mol. Cell 2005, 17, 393-403. [CrossRef] [PubMed]

8. Kuwana, T.; Bouchier-Hayes, L.; Chipuk, J.E.; Bonzon, C.; Sullivan, B.A.; Green, D.R.; Newmeyer, D.D. $\mathrm{BH} 3$ domains of BH3-only proteins differentially regulate Bax-mediated mitochondrial membrane permeabilization both directly and indirectly. Mol. Cell 2005, 17, 525-535. [CrossRef] [PubMed]

9. Hanahan, D.; Weinberg, R.A. The hallmarks of cancer. Cell 2000, 100, 57-70. [CrossRef]

10. Hollstein, M.; Sidransky, D.; Vogelstein, B.; Harris, C.C. p53 mutations in human cancers. Science 1991, 253, 49-53. [CrossRef] [PubMed]

11. Beroukhim, R.; Mermel, C.H.; Porter, D.; Wei, G.; Raychaudhuri, S.; Donovan, J.; Barretina, J.; Boehm, J.S.; Dobson, J.; Urashima, M.; et al. The landscape of somatic copy-number alteration across human cancers. Nature 2010, 463, 899-905. [CrossRef] [PubMed]

12. Van der Heijden, M.; Zimberlin, C.D.; Nicholson, A.M.; Colak, S.; Kemp, R.; Meijer, S.L.; Medema, J.P.; Greten, F.R.; Jansen, M.; Winton, D.J.; et al. Bcl-2 is a critical mediator of intestinal transformation. Nat. Commun. 2016, 7, 10916. [CrossRef] [PubMed]

13. Ni Chonghaile, T.; Sarosiek, K.A.; Vo, T.T.; Ryan, J.A.; Tammareddi, A.; Moore Vdel, G.; Deng, J.; Anderson, K.C.; Richardson, P.; Tai, Y.T.; et al. Pretreatment mitochondrial priming correlates with clinical response to cytotoxic chemotherapy. Science 2011, 334, 1129-1133. [CrossRef] [PubMed]

14. Lee, H.W.; Lee, S.S.; Lee, S.J.; Um, H.D. Bcl-w is expressed in a majority of infiltrative gastric adenocarcinomas and suppresses the cancer cell death by blocking stress-activated protein kinase/c-Jun NH2-terminal kinase activation. Cancer Res. 2003, 63, 1093-1100. [PubMed]

15. Lee, W.S.; Woo, E.Y.; Kwon, J.; Park, M.J.; Lee, J.S.; Han, Y.H.; Bae, I.H. Bcl-w Enhances Mesenchymal Changes and Invasiveness of Glioblastoma Cells by Inducing Nuclear Accumulation of beta-Catenin. PLoS ONE 2013, 8, e68030. [CrossRef]

16. Bae, I.H.; Park, M.J.; Yoon, S.H.; Kang, S.W.; Lee, S.S.; Choi, K.M.; Um, H.D. Bcl-w promotes gastric cancer cell invasion by inducing matrix metalloproteinase-2 expression via phosphoinositide 3-kinase, Akt, and Sp1. Cancer Res. 2006, 66, 4991-4995. [CrossRef] [PubMed]

17. Du, Y.C.; Lewis, B.C.; Hanahan, D.; Varmus, H. Assessing tumor progression factors by somatic gene transfer into a mouse model: Bcl-xL promotes islet tumor cell invasion. PLoS Biol. 2007, 5, e276. [CrossRef] [PubMed]

18. Trisciuoglio, D.; Tupone, M.G.; Desideri, M.; Di Martile, M.; Gabellini, C.; Buglioni, S.; Pallocca, M.; Alessandrini, G.; D’Aguanno, S.; Del Bufalo, D. BCL-XL overexpression promotes tumor progression-associated properties. Cell Death Dis. 2017, 8, 3216. [CrossRef] [PubMed]

19. Choi, S.; Chen, Z.; Tang, L.H.; Fang, Y.; Shin, S.J.; Panarelli, N.C.; Chen, Y.T.; Li, Y.; Jiang, X.; Du, Y.C. Bcl-xL promotes metastasis independent of its anti-apoptotic activity. Nat. Commun. 2016, 7, 10384. [CrossRef] [PubMed]

20. Medan, D.; Luanpitpong, S.; Azad, N.; Wang, L.; Jiang, B.H.; Davis, M.E.; Barnett, J.B.; Guo, L.; Rojanasakul, Y. Multifunctional role of $\mathrm{Bcl}-2$ in malignant transformation and tumorigenesis of $\mathrm{Cr}(\mathrm{VI})$-transformed lung cells. PLoS ONE 2012, 7, e37045. [CrossRef] [PubMed]

21. An, J.; Lv, J.; Li, A.; Qiao, J.; Fang, L.; Li, Z.; Li, B.; Zhao, W.; Chen, H.; Wang, L. Constitutive expression of Bcl-2 induces epithelial-Mesenchymal transition in mammary epithelial cells. BMC Cancer 2015, 15, 476. [CrossRef] [PubMed]

22. Sun, T.; Sun, B.C.; Zhao, X.L.; Zhao, N.; Dong, X.Y.; Che, N.; Yao, Z.; Ma, Y.M.; Gu, Q.; Zong, W.K.; et al. Promotion of tumor cell metastasis and vasculogenic mimicry by way of transcription coactivation by Bcl-2 and Twist1: A study of hepatocellular carcinoma. Hepatology 2011, 54, 1690-1706. [CrossRef] [PubMed] 
23. Liu, Z.; Wild, C.; Ding, Y.; Ye, N.; Chen, H.; Wold, E.A.; Zhou, J. BH4 domain of Bcl-2 as a novel target for cancer therapy. Drug Discov. Today 2016, 21, 989-996. [CrossRef] [PubMed]

24. Villunger, A.; Michalak, E.M.; Coultas, L.; Mullauer, F.; Bock, G.; Ausserlechner, M.J.; Adams, J.M.; Strasser, A. p53- and drug-induced apoptotic responses mediated by BH3-only proteins puma and noxa. Science 2003, 302, 1036-1038. [CrossRef] [PubMed]

25. Hershko, T.; Ginsberg, D. Up-regulation of Bcl-2 homology 3 (BH3)-only proteins by E2F1 mediates apoptosis. J. Biol. Chem. 2004, 279, 8627-8634. [CrossRef] [PubMed]

26. Ekoff, M.; Kaufmann, T.; Engstrom, M.; Motoyama, N.; Villunger, A.; Jonsson, J.I.; Strasser, A.; Nilsson, G. The BH3-only protein Puma plays an essential role in cytokine deprivation induced apoptosis of mast cells. Blood 2007, 110, 3209-3217. [CrossRef] [PubMed]

27. Puthalakath, H.; O’Reilly, L.A.; Gunn, P.; Lee, L.; Kelly, P.N.; Huntington, N.D.; Hughes, P.D.; Michalak, E.M.; McKimm-Breschkin, J.; Motoyama, N.; et al. ER stress triggers apoptosis by activating BH3-only protein Bim. Cell 2007, 129, 1337-1349. [CrossRef] [PubMed]

28. Gatta, R.; Dolfini, D.; Mantovani, R. NF-Y joins E2Fs, p53 and other stress transcription factors at the apoptosis table. Cell Death Dis. 2011, 2, e162. [CrossRef] [PubMed]

29. Zhao, R.; Gish, K.; Murphy, M.; Yin, Y.; Notterman, D.; Hoffman, W.H.; Tom, E.; Mack, D.H.; Levine, A.J. Analysis of p53-regulated gene expression patterns using oligonucleotide arrays. Genes Dev. 2000, 14, 981-993. [PubMed]

30. Morachis, J.M.; Murawsky, C.M.; Emerson, B.M. Regulation of the p53 transcriptional response by structurally diverse core promoters. Genes Dev. 2010, 24, 135-147. [CrossRef] [PubMed]

31. Inuzuka, H.; Fukushima, H.; Shaik, S.; Liu, P.; Lau, A.W.; Wei, W. Mcl-1 ubiquitination and destruction. Oncotarget 2011, 2, 239-244. [CrossRef] [PubMed]

32. Wertz, I.E.; Kusam, S.; Lam, C.; Okamoto, T.; Sandoval, W.; Anderson, D.J.; Helgason, E.; Ernst, J.A.; Eby, M.; Liu, J.; et al. Sensitivity to antitubulin chemotherapeutics is regulated by MCL1 and FBW7. Nature 2011, 471, 110-114. [CrossRef] [PubMed]

33. Del Re, D.P.; Matsuda, T.; Zhai, P.; Maejima, Y.; Jain, M.R.; Liu, T.; Li, H.; Hsu, C.P.; Sadoshima, J. Mst1 promotes cardiac myocyte apoptosis through phosphorylation and inhibition of Bcl-xL. Mol. Cell 2014, 54, 639-650. [CrossRef] [PubMed]

34. Lowman, X.H.; McDonnell, M.A.; Kosloske, A.; Odumade, O.A.; Jenness, C.; Karim, C.B.; Jemmerson, R.; Kelekar, A. The proapoptotic function of Noxa in human leukemia cells is regulated by the kinase Cdk5 and by glucose. Mol. Cell 2010, 40, 823-833. [CrossRef] [PubMed]

35. Hubner, A.; Barrett, T.; Flavell, R.A.; Davis, R.J. Multisite phosphorylation regulates Bim stability and apoptotic activity. Mol. Cell 2008, 30, 415-425. [CrossRef] [PubMed]

36. Fox, J.L.; Ismail, F.; Azad, A.; Ternette, N.; Leverrier, S.; Edelmann, M.J.; Kessler, B.M.; Leigh, I.M.; Jackson, S.; Storey, A. Tyrosine dephosphorylation is required for Bak activation in apoptosis. Embo J. 2010, 29, 3853-3868. [CrossRef] [PubMed]

37. Gardai, S.J.; Hildeman, D.A.; Frankel, S.K.; Whitlock, B.B.; Frasch, S.C.; Borregaard, N.; Marrack, P.; Bratton, D.L.; Henson, P.M. Phosphorylation of Bax Ser184 by Akt regulates its activity and apoptosis in neutrophils. J. Biol. Chem. 2004, 279, 21085-21095. [CrossRef] [PubMed]

38. Xin, M.; Deng, X. Nicotine inactivation of the proapoptotic function of Bax through phosphorylation. J. Biol. Chem. 2005, 280, 10781-10789. [CrossRef] [PubMed]

39. Dumitru, R.; Gama, V.; Fagan, B.M.; Bower, J.J.; Swahari, V.; Pevny, L.H.; Deshmukh, M. Human embryonic stem cells have constitutively active Bax at the Golgi and are primed to undergo rapid apoptosis. Mol. Cell 2012, 46, 573-583. [CrossRef] [PubMed]

40. Edlich, F.; Banerjee, S.; Suzuki, M.; Cleland, M.M.; Arnoult, D.; Wang, C.; Neutzner, A.; Tjandra, N.; Youle, R.J. $\mathrm{Bcl}-\mathrm{x}(\mathrm{L})$ retrotranslocates Bax from the mitochondria into the cytosol. Cell 2011, 145, 104-116. [CrossRef] [PubMed]

41. Bartel, D.P. MicroRNAs: Target recognition and regulatory functions. Cell 2009, 136, 215-233. [CrossRef] [PubMed]

42. Rupaimoole, R.; Slack, F.J. MicroRNA therapeutics: Towards a new era for the management of cancer and other diseases. Nat. Rev. Drug Discov. 2017, 16, 203-222. [CrossRef] [PubMed] 
43. Calin, G.A.; Dumitru, C.D.; Shimizu, M.; Bichi, R.; Zupo, S.; Noch, E.; Aldler, H.; Rattan, S.; Keating, M.; Rai, K.; et al. Frequent deletions and down-regulation of micro-RNA genes miR15 and miR16 at 13q14 in chronic lymphocytic leukemia. Proc. Natl. Acad. Sci. USA 2002, 99, 15524-15529. [CrossRef] [PubMed]

44. Cimmino, A.; Calin, G.A.; Fabbri, M.; Iorio, M.V.; Ferracin, M.; Shimizu, M.; Wojcik, S.E.; Aqeilan, R.I.; Zupo, S.; Dono, M.; et al. miR-15 and miR-16 induce apoptosis by targeting BCL2. Proc. Natl. Acad. Sci. USA 2005, 102, 13944-13949. [CrossRef] [PubMed]

45. Singh, R.; Saini, N. Downregulation of BCL2 by miRNAs augments drug-induced apoptosis-A combined computational and experimental approach. J. Cell Sci. 2012, 125, 1568-1578. [CrossRef] [PubMed]

46. Kuwano, Y.; Nishida, K.; Kajita, K.; Satake, Y.; Akaike, Y.; Fujita, K.; Kano, S.; Masuda, K.; Rokutan, K. Transformer 2beta and miR-204 regulate apoptosis through competitive binding to $3^{\prime}$ UTR of BCL2 mRNA. Cell Death Differ. 2015, 22, 815-825. [CrossRef] [PubMed]

47. Fiori, M.E.; Barbini, C.; Haas, T.L.; Marroncelli, N.; Patrizii, M.; Biffoni, M.; De Maria, R. Antitumor effect of miR-197 targeting in p53 wild-type lung cancer. Cell Death Differ. 2014, 21, 774-782. [CrossRef] [PubMed]

48. Fiori, M.E.; Villanova, L.; Barbini, C.; De Angelis, M.L.; De Maria, R. miR-663 sustains NSCLC by inhibiting mitochondrial outer membrane permeabilization (MOMP) through PUMA/BBC3 and BTG2. Cell Death Dis. 2018, 9, 49. [CrossRef] [PubMed]

49. Fontana, L.; Fiori, M.E.; Albini, S.; Cifaldi, L.; Giovinazzi, S.; Forloni, M.; Boldrini, R.; Donfrancesco, A.; Federici, V.; Giacomini, P.; et al. Antagomir-17-5p abolishes the growth of therapy-resistant neuroblastoma through p21 and BIM. PLoS ONE 2008, 3, e2236. [CrossRef] [PubMed]

50. Kole, A.J.; Swahari, V.; Hammond, S.M.; Deshmukh, M. miR-29b is activated during neuronal maturation and targets BH3-only genes to restrict apoptosis. Genes Dev. 2011, 25, 125-130. [CrossRef] [PubMed]

51. Xiong, Y.; Fang, J.H.; Yun, J.P.; Yang, J.; Zhang, Y.; Jia, W.H.; Zhuang, S.M. Effects of microRNA-29 on apoptosis, tumorigenicity, and prognosis of hepatocellular carcinoma. Hepatology 2010, 51, 836-845. [CrossRef] [PubMed]

52. Mott, J.L.; Kobayashi, S.; Bronk, S.F.; Gores, G.J. mir-29 regulates Mcl-1 protein expression and apoptosis. Oncogene 2007, 26, 6133-6140. [CrossRef] [PubMed]

53. Park, S.Y.; Lee, J.H.; Ha, M.; Nam, J.W.; Kim, V.N. miR-29 miRNAs activate p53 by targeting p85 alpha and CDC42. Nat. Struct. Mol. Biol. 2009, 16, 23-29. [CrossRef] [PubMed]

54. Garzon, R.; Heaphy, C.E.; Havelange, V.; Fabbri, M.; Volinia, S.; Tsao, T.; Zanesi, N.; Kornblau, S.M.; Marcucci, G.; Calin, G.A.; et al. MicroRNA 29b functions in acute myeloid leukemia. Blood 2009, 114, 5331-5341. [CrossRef] [PubMed]

55. Jiang, H.; Zhang, G.; Wu, J.H.; Jiang, C.P. Diverse roles of miR-29 in cancer (review). Oncol. Rep. 2014, 31, 1509-1516. [CrossRef] [PubMed]

56. Tarasov, V.; Jung, P.; Verdoodt, B.; Lodygin, D.; Epanchintsev, A.; Menssen, A.; Meister, G.; Hermeking, H. Differential regulation of microRNAs by p53 revealed by massively parallel sequencing: miR-34a is a p53 target that induces apoptosis and G1-arrest. Cell Cycle 2007, 6, 1586-1593. [CrossRef] [PubMed]

57. Chang, T.C.; Wentzel, E.A.; Kent, O.A.; Ramachandran, K.; Mullendore, M.; Lee, K.H.; Feldmann, G.; Yamakuchi, M.; Ferlito, M.; Lowenstein, C.J.; et al. Transactivation of miR-34a by p53 broadly influences gene expression and promotes apoptosis. Mol. Cell 2007, 26, 745-752. [CrossRef] [PubMed]

58. Kaller, M.; Liffers, S.T.; Oeljeklaus, S.; Kuhlmann, K.; Roh, S.; Hoffmann, R.; Warscheid, B.; Hermeking, H. Genome-wide characterization of miR-34a induced changes in protein and mRNA expression by a combined pulsed SILAC and microarray analysis. Mol. Cell Proteom. 2011, 10, M111 010462. [CrossRef] [PubMed]

59. Welch, C.; Chen, Y.; Stallings, R.L. MicroRNA-34a functions as a potential tumor suppressor by inducing apoptosis in neuroblastoma cells. Oncogene 2007, 26, 5017-5022. [CrossRef] [PubMed]

60. Okada, N.; Lin, C.P.; Ribeiro, M.C.; Biton, A.; Lai, G.; He, X.; Bu, P.; Vogel, H.; Jablons, D.M.; Keller, A.C.; et al. A positive feedback between p53 and miR-34 miRNAs mediates tumor suppression. Genes Dev. 2014, 28, 438-450. [CrossRef] [PubMed]

61. Ji, Q.; Hao, X.; Meng, Y.; Zhang, M.; Desano, J.; Fan, D.; Xu, L. Restoration of tumor suppressor miR-34 inhibits human p53-mutant gastric cancer tumorspheres. BMC Cancer 2008, 8, 266. [CrossRef] [PubMed]

62. Gabellini, C.; Trisciuoglio, D.; Del Bufalo, D. Non-canonical roles of Bcl-2 and Bcl-xL proteins: Relevance of BH4 domain. Carcinogenesis 2017, 38, 579-587. [CrossRef] [PubMed] 
63. Xu, Y.; Zhao, F.; Wang, Z.; Song, Y.; Luo, Y.; Zhang, X.; Jiang, L.; Sun, Z.; Miao, Z.; Xu, H. MicroRNA-335 acts as a metastasis suppressor in gastric cancer by targeting Bcl-w and specificity protein 1 . Oncogene 2012, 31, 1398-1407. [CrossRef] [PubMed]

64. Wang, K.; Chen, X.; Zhan, Y.; Jiang, W.; Liu, X.; Wang, X.; Wu, B. miR-335 inhibits the proliferation and invasion of clear cell renal cell carcinoma cells through direct suppression of BCL-W. Tumour Biol. 2015, 36, 6875-6882. [CrossRef] [PubMed]

65. Reed, J.C. Drug insight: Cancer therapy strategies based on restoration of endogenous cell death mechanisms. Nat. Clin. Pract. Oncol. 2006, 3, 388-398. [CrossRef] [PubMed]

66. Gong, J.; Zhang, J.P.; Li, B.; Zeng, C.; You, K.; Chen, M.X.; Yuan, Y.; Zhuang, S.M. MicroRNA-125b promotes apoptosis by regulating the expression of Mcl-1, Bcl-w and IL-6R. Oncogene 2013, 32, 3071-3079. [CrossRef] [PubMed]

67. He, H.; Tian, W.; Chen, H.; Deng, Y. MicroRNA-101 sensitizes hepatocellular carcinoma cells to doxorubicin-induced apoptosis via targeting Mcl-1. Mol. Med. Rep. 2016, 13, 1923-1929. [CrossRef] [PubMed]

68. Jones, R.L.; Swanton, C.; Ewer, M.S. Anthracycline cardiotoxicity. Expert Opin. Drug Saf. 2006, 5, 791-809. [CrossRef] [PubMed]

69. Takemura, G.; Fujiwara, H. Doxorubicin-induced cardiomyopathy from the cardiotoxic mechanisms to management. Prog. Cardiovasc. Dis. 2007, 49, 330-352. [CrossRef] [PubMed]

70. Xie, Q.; Wang, S.; Zhao, Y.; Zhang, Z.; Qin, C.; Yang, X. MiR-519d impedes cisplatin-resistance in breast cancer stem cells by down-regulating the expression of MCL-1. Oncotarget 2017, 8, 22003-22013. [CrossRef] [PubMed]

71. Ji, Q.; Hao, X.; Zhang, M.; Tang, W.; Yang, M.; Li, L.; Xiang, D.; Desano, J.T.; Bommer, G.T.; Fan, D.; et al. MicroRNA miR-34 inhibits human pancreatic cancer tumor-initiating cells. PLoS ONE 2009, 4, e6816. [CrossRef] [PubMed]

72. Zhao, J.J.; Chu, Z.B.; Hu, Y.; Lin, J.; Wang, Z.; Jiang, M.; Chen, M.; Wang, X.; Kang, Y.; Zhou, Y.; et al. Targeting the miR-221-222/PUMA/BAK/BAX Pathway Abrogates Dexamethasone Resistance in Multiple Myeloma. Cancer Res. 2015, 75, 4384-4397. [CrossRef] [PubMed]

73. Schmitt, A.M.; Chang, H.Y. Long Noncoding RNAs in Cancer Pathways. Cancer Cell 2016, 29, 452-463. [CrossRef] [PubMed]

74. Villanova, L.; Micol, E. De-coding stemness pathways in cancer. J. Stem Cell Res. Ther. 2016, 1. [CrossRef]

75. Chen, J.; Liu, L.; Wei, G.; Wu, W.; Luo, H.; Yuan, J.; Luo, J.; Chen, R. The long noncoding RNA ASNR regulates degradation of Bcl-2 mRNA through its interaction with AUF1. Sci. Rep. 2016, 6, 32189. [CrossRef] [PubMed]

76. Xie, H.; Liao, X.; Chen, Z.; Fang, Y.; He, A.; Zhong, Y.; Gao, Q.; Xiao, H.; Li, J.; Huang, W.; et al. LncRNA MALAT1 Inhibits Apoptosis and Promotes Invasion by Antagonizing miR-125b in Bladder Cancer Cells. J. Cancer 2017, 8, 3803-3811. [CrossRef] [PubMed]

77. Han, Y.; Liu, Y.; Zhang, H.; Wang, T.; Diao, R.; Jiang, Z.; Gui, Y.; Cai, Z. Hsa-miR-125b suppresses bladder cancer development by down-regulating oncogene SIRT7 and oncogenic long noncoding RNA MALAT1. FEBS Lett. 2013, 587, 3875-3882. [CrossRef] [PubMed]

78. Sun, Y.; Hu, B.; Wang, Q.; Ye, M.; Qiu, Q.; Zhou, Y.; Zeng, F.; Zhang, X.; Guo, Y.; Guo, L. Long non-coding RNA HOTTIP promotes BCL-2 expression and induces chemoresistance in small cell lung cancer by sponging miR-216a. Cell Death Dis. 2018, 9, 85. [CrossRef] [PubMed]

79. Ding, W.; Ren, J.; Ren, H.; Wang, D. Long Noncoding RNA HOTAIR Modulates MiR-206-mediated Bcl-w Signaling to Facilitate Cell Proliferation in Breast Cancer. Sci. Rep. 2017, 7, 17261. [CrossRef] [PubMed]

80. Wang, K.; Jin, W.; Song, Y.; Fei, X. LncRNA RP11-436H11.5, functioning as a competitive endogenous RNA, upregulates BCL-W expression by sponging miR-335-5p and promotes proliferation and invasion in renal cell carcinoma. Mol. Cancer 2017, 16, 166. [CrossRef] [PubMed]

81. Liu, H.; Zhou, G.; Fu, X.; Cui, H.; Pu, G.; Xiao, Y.; Sun, W.; Dong, X.; Zhang, L.; Cao, S.; et al. Long noncoding RNA TUG1 is a diagnostic factor in lung adenocarcinoma and suppresses apoptosis via epigenetic silencing of BAX. Oncotarget 2017, 8, 101899-101910. [CrossRef] [PubMed]

82. Sanchez, Y.; Segura, V.; Marin-Bejar, O.; Athie, A.; Marchese, F.P.; Gonzalez, J.; Bujanda, L.; Guo, S.; Matheu, A.; Huarte, M. Genome-wide analysis of the human p53 transcriptional network unveils a lncRNA tumour suppressor signature. Nat. Commun. 2014, 5, 5812. [CrossRef] [PubMed] 
83. Hung, T.; Wang, Y.; Lin, M.F.; Koegel, A.K.; Kotake, Y.; Grant, G.D.; Horlings, H.M.; Shah, N.; Umbricht, C.; Wang, P.; et al. Extensive and coordinated transcription of noncoding RNAs within cell-cycle promoters. Nat. Genet. 2011, 43, 621-629. [CrossRef] [PubMed]

84. Li, Y.; Zheng, Q.; Bao, C.; Li, S.; Guo, W.; Zhao, J.; Chen, D.; Gu, J.; He, X.; Huang, S. Circular RNA is enriched and stable in exosomes: A promising biomarker for cancer diagnosis. Cell Res. 2015, 25, 981-984. [CrossRef] [PubMed]

85. Memczak, S.; Jens, M.; Elefsinioti, A.; Torti, F.; Krueger, J.; Rybak, A.; Maier, L.; Mackowiak, S.D.; Gregersen, L.H.; Munschauer, M.; et al. Circular RNAs are a large class of animal RNAs with regulatory potency. Nature 2013, 495, 333-338. [CrossRef] [PubMed]

86. Hansen, T.B.; Jensen, T.I.; Clausen, B.H.; Bramsen, J.B.; Finsen, B.; Damgaard, C.K.; Kjems, J. Natural RNA circles function as efficient microRNA sponges. Nature 2013, 495, 384-388. [CrossRef] [PubMed]

87. Zheng, Q.; Bao, C.; Guo, W.; Li, S.; Chen, J.; Chen, B.; Luo, Y.; Lyu, D.; Li, Y.; Shi, G.; et al. Circular RNA profiling reveals an abundant circHIPK3 that regulates cell growth by sponging multiple miRNAs. Nat. Commun. 2016, 7, 11215. [CrossRef] [PubMed]

88. Zhang, H.; Wang, G.; Ding, C.; Liu, P.; Wang, R.; Ding, W.; Tong, D.; Wu, D.; Li, C.; Wei, Q.; et al. Increased circular RNA UBAP2 acts as a sponge of miR-143 to promote osteosarcoma progression. Oncotarget 2017, 8, 61687-61697. [CrossRef] [PubMed]

89. Du, W.W.; Fang, L.; Yang, W.; Wu, N.; Awan, F.M.; Yang, Z.; Yang, B.B. Induction of tumor apoptosis through a circular RNA enhancing Foxo3 activity. Cell Death Differ. 2017, 24, 357-370. [CrossRef] [PubMed]

90. Anastasiadou, E.; Jacob, L.S.; Slack, F.J. Non-coding RNA networks in cancer. Nat. Rev. Cancer 2018, 18, 5-18. [CrossRef] [PubMed]

91. International Human Genome Sequencing Consortium. Finishing the euchromatic sequence of the human genome. Nature 2004, 431, 931-945. [CrossRef]

92. The ENCODE Project Consortium. An integrated encyclopedia of DNA elements in the human genome. Nature 2012, 489, 57-74. [CrossRef]

93. Ashkenazi, A.; Fairbrother, W.J.; Leverson, J.D.; Souers, A.J. From basic apoptosis discoveries to advanced selective BCL-2 family inhibitors. Nat. Rev. Drug Discov. 2017, 16, 273-284. [CrossRef] [PubMed]

94. Oltersdorf, T.; Elmore, S.W.; Shoemaker, A.R.; Armstrong, R.C.; Augeri, D.J.; Belli, B.A.; Bruncko, M.; Deckwerth, T.L.; Dinges, J.; Hajduk, P.J.; et al. An inhibitor of Bcl-2 family proteins induces regression of solid tumours. Nature 2005, 435, 677-681. [CrossRef] [PubMed]

95. Roberts, A.W.; Seymour, J.F.; Brown, J.R.; Wierda, W.G.; Kipps, T.J.; Khaw, S.L.; Carney, D.A.; He, S.Z.; Huang, D.C.; Xiong, H.; et al. Substantial susceptibility of chronic lymphocytic leukemia to BCL2 inhibition: Results of a phase I study of navitoclax in patients with relapsed or refractory disease. J. Clin. Oncol. 2012, 30, 488-496. [CrossRef] [PubMed]

96. Kipps, T.J.; Eradat, H.; Grosicki, S.; Catalano, J.; Cosolo, W.; Dyagil, I.S.; Yalamanchili, S.; Chai, A.; Sahasranaman, S.; Punnoose, E.; et al. A phase 2 study of the BH3 mimetic BCL2 inhibitor navitoclax (ABT-263) with or without rituximab, in previously untreated B-cell chronic lymphocytic leukemia. Leuk Lymphoma 2015, 56, 2826-2833. [CrossRef] [PubMed]

97. Kipps, T.J. Navitoclax (ABT-263) Plus Fludarabine/Cyclophosphamide/Rituximab (FCR) or Bendamustine/ Rituximab (BR): A Phase 1 Study in Patients with Relapsed/Refractory Chronic Lymphocytic Leukemia (CLL). Blood 2011, 118, 3904.

98. Mason, K.D.; Carpinelli, M.R.; Fletcher, J.I.; Collinge, J.E.; Hilton, A.A.; Ellis, S.; Kelly, P.N.; Ekert, P.G.; Metcalf, D.; Roberts, A.W.; et al. Programmed anuclear cell death delimits platelet life span. Cell 2007, 128, 1173-1186. [CrossRef] [PubMed]

99. Zhang, H.; Nimmer, P.M.; Tahir, S.K.; Chen, J.; Fryer, R.M.; Hahn, K.R.; Iciek, L.A.; Morgan, S.J.; Nasarre, M.C.; Nelson, R.; et al. Bcl-2 family proteins are essential for platelet survival. Cell Death Differ. 2007, 14, 943-951. [CrossRef] [PubMed]

100. Souers, A.J.; Leverson, J.D.; Boghaert, E.R.; Ackler, S.L.; Catron, N.D.; Chen, J.; Dayton, B.D.; Ding, H.; Enschede, S.H.; Fairbrother, W.J.; et al. ABT-199, a potent and selective BCL-2 inhibitor, achieves antitumor activity while sparing platelets. Nat. Med. 2013, 19, 202-208. [CrossRef] [PubMed]

101. Stilgenbauer, S.; Eichhorst, B.; Schetelig, J.; Coutre, S.; Seymour, J.F.; Munir, T.; Puvvada, S.D.; Wendtner, C.M.; Roberts, A.W.; Jurczak, W.; et al. Venetoclax in relapsed or refractory chronic lymphocytic leukaemia with 17p deletion: A multicentre, open-label, phase 2 study. Lancet Oncol. 2016, 17, 768-778. [CrossRef] 
102. Konopleva, M.; Contractor, R.; Tsao, T.; Samudio, I.; Ruvolo, P.P.; Kitada, S.; Deng, X.; Zhai, D.; Shi, Y.X.; Sneed, T.; et al. Mechanisms of apoptosis sensitivity and resistance to the BH3 mimetic ABT-737 in acute myeloid leukemia. Cancer Cell 2006, 10, 375-388. [CrossRef] [PubMed]

103. Van Delft, M.F.; Wei, A.H.; Mason, K.D.; Vandenberg, C.J.; Chen, L.; Czabotar, P.E.; Willis, S.N.; Scott, C.L.; Day, C.L.; Cory, S.; et al. The BH3 mimetic ABT-737 targets selective Bcl-2 proteins and efficiently induces apoptosis via Bak/Bax if Mcl-1 is neutralized. Cancer Cell 2006, 10, 389-399. [CrossRef] [PubMed]

104. Leverson, J.D.; Zhang, H.; Chen, J.; Tahir, S.K.; Phillips, D.C.; Xue, J.; Nimmer, P.; Jin, S.; Smith, M.; Xiao, Y.; et al. Potent and selective small-molecule MCL-1 inhibitors demonstrate on-target cancer cell killing activity as single agents and in combination with ABT-263 (navitoclax). Cell Death Dis. 2015, 6, e1590. [CrossRef] [PubMed]

105. Meynet, O.; Zunino, B.; Happo, L.; Pradelli, L.A.; Chiche, J.; Jacquin, M.A.; Mondragon, L.; Tanti, J.F.; Taillan, B.; Garnier, G.; et al. Caloric restriction modulates Mcl-1 expression and sensitizes lymphomas to BH3 mimetic in mice. Blood 2013, 122, 2402-2411. [CrossRef] [PubMed]

106. Cerella, C.; Gaigneaux, A.; Mazumder, A.; Lee, J.Y.; Saland, E.; Radogna, F.; Farge, T.; Vergez, F.; Recher, C.; Sarry, J.E.; et al. Bcl-2 protein family expression pattern determines synergistic pro-apoptotic effects of BH3 mimetics with hemisynthetic cardiac glycoside UNBS1450 in acute myeloid leukemia. Leukemia 2017, 31, 755-759. [CrossRef] [PubMed]

107. Adams, B.D.; Anastasiadou, E.; Esteller, M.; He, L.; Slack, F.J. The Inescapable Influence of Noncoding RNAs in Cancer. Cancer Res. 2015, 75, 5206-5210. [CrossRef] [PubMed]

108. MacDiarmid, J.A.; Mugridge, N.B.; Weiss, J.C.; Phillips, L.; Burn, A.L.; Paulin, R.P.; Haasdyk, J.E.; Dickson, K.A.; Brahmbhatt, V.N.; Pattison, S.T.; et al. Bacterially derived $400 \mathrm{~nm}$ particles for encapsulation and cancer cell targeting of chemotherapeutics. Cancer Cell 2007, 11, 431-445. [CrossRef] [PubMed]

109. Van Zandwijk, N.; Pavlakis, N.; Kao, S.C.; Linton, A.; Boyer, M.J.; Clarke, S.; Huynh, Y.; Chrzanowska, A.; Fulham, M.J.; Bailey, D.L.; et al. Safety and activity of microRNA-loaded minicells in patients with recurrent malignant pleural mesothelioma: A first-in-man, phase 1, open-label, dose-escalation study. Lancet Oncol. 2017, 18, 1386-1396. [CrossRef] 